\title{
Muscular characters in the phylogeny of Liolaemus (Squamata: Iguania: Liolaemidae): a reappraisal
}

\author{
V. ABDALA ${ }^{1}$, C. ABDALA $^{2} \&$ M.J. TULLI ${ }^{3}$ \\ ${ }^{1,2}$ Instituto de Herpetología, Fundación Miguel Lillo, CONICET, Miguel Lillo 251, San Miguel de Tucumán, \\ Argentina. E-mail: virginia@webmail.unt.edu.ar \\ ${ }^{1,3}$ Cátedra de Biología General, Facultad de Ciencias Naturales, Universidad Nacional de Tucumán, Miguel \\ Lillo 205, San Miguel de Tucumán, Argentina
}

\begin{abstract}
Liolaemus is one of the most speciosus genera of lizards, having more than 200 species. It is composed of small to moderate-sized lizards that live throughout most of austral South America. Many groups whose phylogenetic relationships have been controversial compose the genus. The proposed phylogenetic relationships of these lizards have been based on data-sets from many sources. In all of the morphological data-sets, three myologycal characters have been considered particularly important:1) insertion of the $\mathrm{m}$. tibialis anticus hypertrophied in association with the presence of a sharp, bladelike process of the tibia, 2) medial head of the m. flexor tibialis internus covered by a hypertrophied m. puboisquitibialis, and 3) presence of melanic pigment within the medial portion of the epimysium of the m. pterygomandibularis. Important taxonomic and anatomical questions about these characters remain: 1) Can the size of the m. puboisquiotibilis be scored with only two character states? 2) Is there a close relationship between the hypertrophied $\mathrm{m}$. flexor tibialis internus and the patch of the enlarged proximal postfemoral scales? and 3) Are these muscular characters exclusive to some of the groups of Liolaemus that have been proposed? Focusing on these questions, we have conducted a taxonomic and anatomic review of these characters in 42 species representing all of the proposed groups of Liolaemus. The analyzed samples show that variations in the considered muscular characters are much more gradual than previously stated. The only exception is the insertion of the m. tibialis anticus hypertrophied in relation to a bladelike hypertrophy of the tibia, which characterizes the montanus group of $\mathrm{E}$ theridge (1995). These characters seem to have the same phylogenetic information as any other morphological character. Although the coding we used is more complex, it shows more precisely the subtlety of the change in the character states.
\end{abstract}

Key words: Liolaemus, cranial and limb myology characters, phylogeny 
Liolaemus is one of the most speciosus genera of lizards. It is composed of small to moderate-sized lizards that live throughout most of austral South America. Liolaemus ranges from northern central Peru southward through Bolivia, Chile, and Argentina to northern Tierra del Fuego, and up the Atlantic coast of Uruguay and southeastern Brazil. Members of this genus occur at elevations from sea level to over $5000 \mathrm{~m}$. Liolaemus may be insectivorous or herbivorous, but the majority of species appear to be omnivorous. The majority of liolaemid lizards live in arid or semiarid habitats, but the distributions of some Liolaemus extend into the humid forest of southern Chile, and along the Atlantic coast including several Brazilian islands. Liolaemids are almost entirely terrestrial, with most being microhabitat generalists, but some are highly specialized morphologically: some Liolaemus live their whole lives on aeolian sand, whereas others among crevices in boulder outcrops. Only Liolaemus tenuis (Duméril \& Bibron) is commonly found on trees (Etheridge \& Espinoza 2005).

Many groups whose phylogenetic relationships have been controversial belong to this genus. The proposed phylogenetic relationships of these South American lizards have been based on data sets from many sources: osteological and external morphology (e.g. E theridge 1995, 2000; Lobo \& Abdala 2002; Abdala 2005); ethological (Halloy et al. 1998); myological (Moro \& Abdala 1998); molecular (Schulte et al. 2000; Morando 2004; Abdala 2005) etc. In the morphological data sets that were used, three characters have been frequently considered:

Insertion of the m. tibialis anticus hypertrophied in association with the presence of a sharp, bladelike process of the tibia (proposed by Etheridge 1995).

Medial head of the $\mathrm{m}$. flexor tibialis internus is covered by a hypertrophied $\mathrm{m}$. puboisquitibialis (proposed by Etheridge 1995).

Presence of melanic pigment within the medial portion of the epimysium of the $\mathrm{m}$. pterygomandibularis (proposed by Etheridge 1995).

These have been considered decisive characters in supporting many of the Liolaemus groups. Etheridge (1995) presented a taxonomic revision of the Liolaemidae that considered its three genera, Ctenoblepharys, Phymaturus and Liolaemus to form an unresolved polytomy. For the genus Liolaemus, he proposed an indented classification. Liolaemus archeforus Donoso-Barros \& Cei and L. kingii Bell were considered basal, and the remaining species were placed in two large groups, the nitidus and signifer groups. The nitidus group included the basal species L. magellanicus Hombron \& Jaquinot, plus a small lineomamaculatus group and a large chiliensis group, which was, for the most part, equal to the Chileno group of Laurent (1983). The signifier group included the basal species L. anomalus Koslowsky and L. pseudoanomalus Cei and a large montanus group, for the most part equivalent to the Argentino group of Laurent (1983). It was for the species of the signifer group that Etheridge (1995) employed the three morphological characters listed above: presence of pigmented epimysium of the m. pterygomandibularis 
and hyperophied medial head of the $\mathrm{m}$. flexor tibialis internus were proposed synapomorphies for the entire signifer group; a sharp, bladelike process of the tibia associated with a hypertrophied $\mathrm{m}$ tibialis anterior was given as a synapomorphy of the montanus group (i.e., all species of the signifer group except $L$. anomalus and $L$. pseudoanomalus), and a patch of abruptly enlarged, spinose scales on the posterior medial surface of the thigh, bulged out in adult males due to hypertrophy of underlying $\mathrm{m}$. puboischisotibialis were proposed as synapomorphies of the boulengeri group, a subset of the montanus group. A subset of the boulengeri group, the wiegmannii group, was also proposed based on certain head scale characteristics.

According to a DNA analysis of Schulte et al. (2000), Morando (2004), and Abdala (2005), L. pseudoanomalus is the sister species of the wiegmannii group, and $L$. chacoensis Shreeve, placed in the chiliensis group by Etheridge (1995), is closely related to L. darwinii (Bell), but neither has the tibial blade nor the hypertrophied $\mathrm{m}$. puboisquiotibialis. Liolaemus chacoensis does, however, have enlarged proximal postfemoral scales but they do not form a distinct "patch". Several austral species (e.g. $L$. magellanicus, L. lineomaculatus Boulenger, L. hatcheri Stejneger, L. sylvanae DonosoBarros \& Cei) also have some enlarged proximal postfemoral scales but lack a hypertrophied m. puboisquiotibialis. These species, along with the chiliensis group, were included in the nitidus group by Etheridge (1995). Schulte et al. (2000), however, placed them as basal members of the montanus group.

Etheridge (2000) proposed a phylogenetic hypothesis for the wiegmannii group, included within an analysis of the boulengeri group. In his data set, he includes the perimysium pigmentation of the $\mathrm{m}$. pterygomandibularis character (his character 38), considering only two character states: with and without pigmentation. The species $L$. multimaculatus (Duméril \& Bibron), L. rabinoi (Cei), L. riojanus Cei, and southern populations of $L$. cuyanus Cei \& Scolaro were scored as "without pigmentation." Lobo and Abdala (2002), and Abdala (2005) also scored that character for their analysis of 24 species of the most important groups of Liolaemus, and the boulengeri group respectively. In these latter analyses the character was scored following the proposal of Etheridge (1995). Moro and Abdala (1998) added one more state for this character (ligthly pigmented), having in their analysis only some overlap with that of Etheridge (1995).

Thus, important anatomical and taxonomic questions concerning these characters remain: 1) Is the size of the m. puboisquiotibilis scorable with only two character states: normal and hypertrophied? Or is variation continuous? 2) Is there a close relation between the hypertrophied $\mathrm{m}$. flexor tibialis internus and the patch of the enlarged proximal postfemoral scales? 3) are these muscular characters exclusive to any of the many Liolaemus groups?

Focusing on these questions, we present in this study an analysis of the afore mentioned characters in 42 species representing each of the groups of Liolaemus proposed by Etheridge (1995), and one species of Phymaturus, the sister taxon of Liolaemus. We 
consider the morphology of the aforementioned muscles, and their distribution in different taxa. We also include a quantification of the area corresponding to the hypertrophy of the flexor tibialis internus muscle.

\section{Material and methods}

Sixty specimens belonging to 42 species of Liolaemus and one species of Phymaturus (Appendix 1) were used in the analysis. Macroscopic observations of the muscles were performed following usual laboratory techniques, with the aid of a binocular dissection microscope. Muscles were classified using the terminology proposed by Russell (1988, 1993) and Hoyos (1990) for fore and hind limbs and cranial muscles after Moro and Abdala (1998). Descriptions of the muscles examined are included. Variations are included in Table 1. Discussion is included under remarks.

To obtain the quantification of the area of the hypertrophy of the muscles, photos of the thigh were taken with a digital camera. Photos taken using the same scale were processed using the "Image tool 3.0" program to obtain the hypertrophied $\mathrm{m}$. flexor tibialis internus area, which is related to the area of the m. puboisquiotibialis, to eliminate the size distortion. The resultant ratios are given in Table 2 .

\section{Results and discussion}

M. puboisquiotibialis: it originates from the ischiopubic ligament. It has parallel fibers, and is very broad. It covers a wide ventral surface of the thigh. Although some separation of the fibers can be seen, in most cases the muscle is composed by only one large portion. It inserts fleshily on the 4th proximal portion of the tibia. At its insertion the $\mathrm{m}$. puboischiotibialis is joined by a slip of the $\mathrm{m}$. flexor tibialis internus. Both muscles unite in a pennate fashion.

Remarks. We considered, as Etheridge (1995) did, that a hypertrophied $\mathrm{m}$. puboisquiotibialis covers the medial head of $\mathrm{m}$. flexor tibialis internus. This is the definition of our character state "hypertophied" for this muscle. It should not be taken to mean a larger muscle. The variations of this character can be seen in Table 1.

We observed two character states for this muscle: normal (Fig. 3) and hypertrophied (Fig.1). We agree with Etheridge (1995) with respect to the sexual dimorphism present in signifer group. The muscle is hypertrophied in the species of the boulengeri, and wiegmannii groups, and $L$. andinus Koslowsky, $L$. huacahuasicus Laurent, $L$. pulcherrimus Laurent, and L. multicolor Koslowsky (montanus group), also in agreement with Etheridge's observations. However, the hypertrophied muscle was also observed in some species of the chiliensis group (L. bitaeniatus Laurent, L. robermertensis Hellmich, and L. pagaburoi Lobo \& $\quad$ Espinoza), and also in L. kingii and Phymaturus 
somuncurensis Cei \& Castro. Thus, this character is not exclusive to any Liolaemus group, but it is defined by in two character states.

M. flexor tibialis internus: it has two bellies. The most superficial one arises from the ilioischiadic ligament, ventral to the $\mathrm{m}$. puboischiotibialis. This belly shares many fibers with the m. puboischiotibialis at its origin. It is flat, and covers the deep portion of the $\mathrm{m}$. flexor tibialis internus and the m. puboischiotibialis. It inserts tendinously on the proximal portion of the tibia, ventral to the insertion of the m. puboischiotibialis. The deep portion arises also from the puboischiadic ligament, internal to the origin of the superficial portion; it is cordon-like, rather bulky, and inserts tendinously onto the latero-proximal extremity of the tibia. This muscle is covered dorsally by the m. puboischiotibialis and latero-ventrally by the superficial portion of the $\mathrm{m}$. flexor tibialis internus.

Remarks. In many species of Liolaemus (Table 1), the superficial belly of this muscle has a bulged-out portion. It can be seen externally as a ventral protuberance of the thigh (Fig. 1). A patch of enlarged scales sometimes covers this protuberance (Table 1). Our character states were: $\mathrm{m}$. flexor tibialis internus hypertrophy absent, small, or bulge-like. The bulge-like structure is observed in the boulengeri group. An exception is one male specimen listed as $L$. cf. ornatus from Catamarca province, which has no bulge. Etheridge (1993) designated as the type locality of L. ornatus Koslowsky, 3km W of Abra Pampa (Jujuy province). All specimens from that location have a large bulge of the $\mathrm{m}$. flexor tibialis internus. Probably our scored differences are due to our examination of two different species. The hypertrophy is small in the wiegmannii group. Some species of the montanus group ( $L$. andinus, and $L$. huacahuasicus) have no hypertrophy, whereas others have the bulge-like structure (e.g., L. pulcherrimus). This character is polymorphic in $L$. multicolor, as we have one specimen with, and one without a bulge (Table 1). Meanwhile the character states of hypertrophy, absent or small, are seen in the chiliensis, and lineomaculatus groups, and in L. kingii. We disagree with Etheridge (1995) with respect to $L$. andinus and $L$. huacahuasicus of the montanus group, which he described to be without hypertrophy.

We agree with Etheridge (pers. comm.) that some fibers of the m. flexor tibialis internus insert on the skin, resulting by their contraction in the overlying skin to form a larger bulge.

Considering the ratio between the areas of both muscles (Table 2), we found a range that shows great overlap among different species (Fig. 5, 2). In this range, it makes no sense to recognize only three character states (normal, lightly hypertrophied, and hypertrophied) since they all share the same morphological space. The most logical option is to consider variation in this character as continuous.

The groups formed using traditional character states are not in agreement with any of the phylogenetic groups established so far. 
TABLE 1. Taxa and character states of myologycal traits analysed.

\begin{tabular}{|c|c|c|c|c|c|}
\hline Specie & $\begin{array}{l}\text { M. } \\
\text { puboisquiotibialis }\end{array}$ & $\begin{array}{l}\text { M. flexor } \\
\text { tibialis internus } \\
\text { hypertrophy }\end{array}$ & M. tibialis anticus & patch & $\begin{array}{l}\text { M. } \\
\text { pterygomandibul } \\
\text { aris epimysium }\end{array}$ \\
\hline L. abaucan $\mathrm{o}^{x}$ & hypertrophied & bulge-like & hypertrophied & present & pigmented \\
\hline L. albiceps $\sigma^{\pi}$ & hypertrophied & bulge-like & hypertrophied & present & pigmented \\
\hline L. albiceps 우 & normal & bulge-like & hypertrophied & present & pigmented \\
\hline L. boulengeri $\sigma^{\star}$ & hypertrophied & bulge-like & hypertrophied & present & pigmented \\
\hline L. canqueli $\sigma^{\pi}$ & hypertrophied & bulge-like & hypertrophied & present & pigmented \\
\hline L. cf. boulengeri 우 & normal & bulge-like & hypertrophied & present & pigmented \\
\hline L. cf. boulengeri $\sigma^{x}$ & hypertrophied & bulge-like & hypertrophied & present & pigmented \\
\hline L. cuyanus $\sigma^{\pi}$ & hypertrophied & bulge-like & hypertrophied & present & no pigmented \\
\hline L. darwinii $0^{x}$ & hypertrophied & bulge-like & hypertrophied & present & polimorphism \\
\hline L. fitzingerii $\sigma^{x}$ & hypertrophied & bulge-like & hypertrophied & present & pigmented \\
\hline L. inacayali 우 & normal & bulge-like & hypertrophied & present & pigmented \\
\hline L. irregularis $0^{x}$ & hypertrophied & bulge-like & hypertrophied & present & pigmented \\
\hline L. koslowskyi $0^{\star}$ & hypertrophied & bulge-like & hypertrophied & present & pigmented \\
\hline L. loboi $0^{x}$ & hypertrophied & bulge-like & hypertrophied & present & pigmented \\
\hline L. sagei $0^{x}$ & hypertrophied & bulge-like & hypertrophied & present & pigmented \\
\hline L. uspallatensis 우 & normal & bulge-like & hypertrophied & present & pigmented \\
\hline L. xanthoviridis 우 & normal & bulge-like & hypertrophied & present & no pigmented \\
\hline L. cf. anomalus $0^{x}$ & normal & small & normal & present & pigmented \\
\hline L. cf. ornatus $\sigma^{x}$ & hypertrophied & small & hypertrophied & present & no data \\
\hline L. chacoensis 우 & hypertrophied & small & normal & present & pigmented \\
\hline L. pseudoanomalus $0^{\star}$ & normal & small & normal & present & pigmented \\
\hline L. salinícola $\sigma^{x}$ & hypertrophied & small & hypertrophied & present & pigmented \\
\hline L. scapularis $0^{\pi}$ & hypertrophied & small & hypertrophied & present & pigmented \\
\hline L. bibroni 우 & normal & absent & normal & absent & few pigmented \\
\hline L. bibroni $\sigma^{\pi}$ & normal & absent & normal & absent & few pigmented \\
\hline L. bitaeniatus $\sigma^{x}$ & hypertrophied & absent & normal & absent & few pigmented \\
\hline L. cf andinus 우 & hypertrophied & absent & hypertrophied & absent & no pigmented \\
\hline L. chaltin ㅇ & normal & absent & normal & absent & $\begin{array}{l}\text { almost without } \\
\text { pigmentation }\end{array}$ \\
\hline L. chaltin $0^{\pi}$ & normal & absent & normal & absent & $\begin{array}{l}\text { almost without } \\
\text { pigmentation }\end{array}$ \\
\hline L. huacahuasicus ox & hypertrophied & absent & hypertrophied & absent & pigmented \\
\hline L. lineomaculatus 우 & normal & absent & normal & absent & few pigmented \\
\hline L. lineomaculatus ox & normal & absent & normal & absent & few pigmented \\
\hline
\end{tabular}


TABLE 1 (continued).

\begin{tabular}{|c|c|c|c|c|c|}
\hline Specie & $\begin{array}{l}\text { M. } \\
\text { puboisquiotibialis }\end{array}$ & $\begin{array}{l}\text { M. flexor } \\
\text { tibialis internus } \\
\text { hypertrophy }\end{array}$ & M. tibialis anticus & patch & $\begin{array}{l}\text { M. } \\
\text { pterygomandibul } \\
\text { aris epimysium }\end{array}$ \\
\hline L. magellanicus 우 & normal & absent & normal & absent & few pigmented \\
\hline L. magellanicus $0^{x}$ & normal & absent & normal & absent & few pigmented \\
\hline L. multicolor 우 & normal & absent & hypertrophied & absent & pigmented \\
\hline L. multicolor $\sigma^{\pi}$ & hypertrophied & bulge-like & hypertrophied & absent & pigmented \\
\hline L. neuquensis & normal & absent & normal & absent & $\begin{array}{l}\text { almost without } \\
\text { pigmentation }\end{array}$ \\
\hline L. neuquensis o $^{\star}$ & normal & absent & normal & absent & $\begin{array}{l}\text { almost without } \\
\text { pigmentation }\end{array}$ \\
\hline L. petrophilus $\mathrm{o}^{x}$ & normal & absent & normal & absent & few pigmented \\
\hline L. puna ㅇ & normal & absent & normal & absent & $\begin{array}{l}\text { almost without } \\
\text { pigmentation }\end{array}$ \\
\hline L. puna $\sigma^{x}$ & normal & absent & normal & absent & $\begin{array}{l}\text { almost without } \\
\text { pigmentation }\end{array}$ \\
\hline L. robertmertensis $\sigma^{\star}$ & hypertrophied & absent & normal & absent & no pigmented \\
\hline L. escarchadosi 우 & normal & absent & normal & absent & few pigmented \\
\hline L. escarchadosi $\sigma^{*}$ & normal & absent & normal & absent & few pigmented \\
\hline L. talampaya & normal & absent & normal & absent & $\begin{array}{l}\text { almost without } \\
\text { pigmentation }\end{array}$ \\
\hline L. talampaya $\sigma^{x}$ & normal & absent & normal & absent & pigmented \\
\hline L. yanalcu $\sigma^{x}$ & normal & absent & normal & absent & $\begin{array}{l}\text { almost without } \\
\text { pigmentation }\end{array}$ \\
\hline L. zullyi & normal & absent & normal & absent & $\begin{array}{l}\text { almost without } \\
\text { pigmentation }\end{array}$ \\
\hline L. zullyi $\sigma^{x}$ & normal & absent & normal & absent & $\begin{array}{l}\text { almost without } \\
\text { pigmentation }\end{array}$ \\
\hline L. kingii $\sigma^{x}$ & hypertrophied & bulge-like & normal & absent & few pigmented \\
\hline L.cf. pulcherrimus $\sigma^{x}$ & hypertrophied & bulge-like & hypertrophied & absent & pigmented \\
\hline L. bibroni व $^{x}$ & normal & small & normal & absent & few pigmented \\
\hline L. ceii 우 & normal & small & normal & absent & few pigmented \\
\hline L. elongatus 우 & normal & small & normal & absent & few pigmented \\
\hline L. hatcheri 우 & normal & small & normal & absent & few pigmented \\
\hline L. hatcheri $\sigma^{\pi}$ & normal & small & normal & absent & few pigmented \\
\hline L. pagaburoi ox & hypertrophied & small & normal & absent & few pigmented \\
\hline Phymaturus sp o ${ }^{x}$ & hypertrophied & small & normal & absent & no pigmented \\
\hline $\begin{array}{l}\text { Diplolaemus darwinii } \\
\sigma^{*}\end{array}$ & hypertrophied & absent & normal & absent & no pigmented \\
\hline Iguana iguana $\mathrm{o}^{x}$ & normal & absent & normal & absent & few pigmented \\
\hline
\end{tabular}



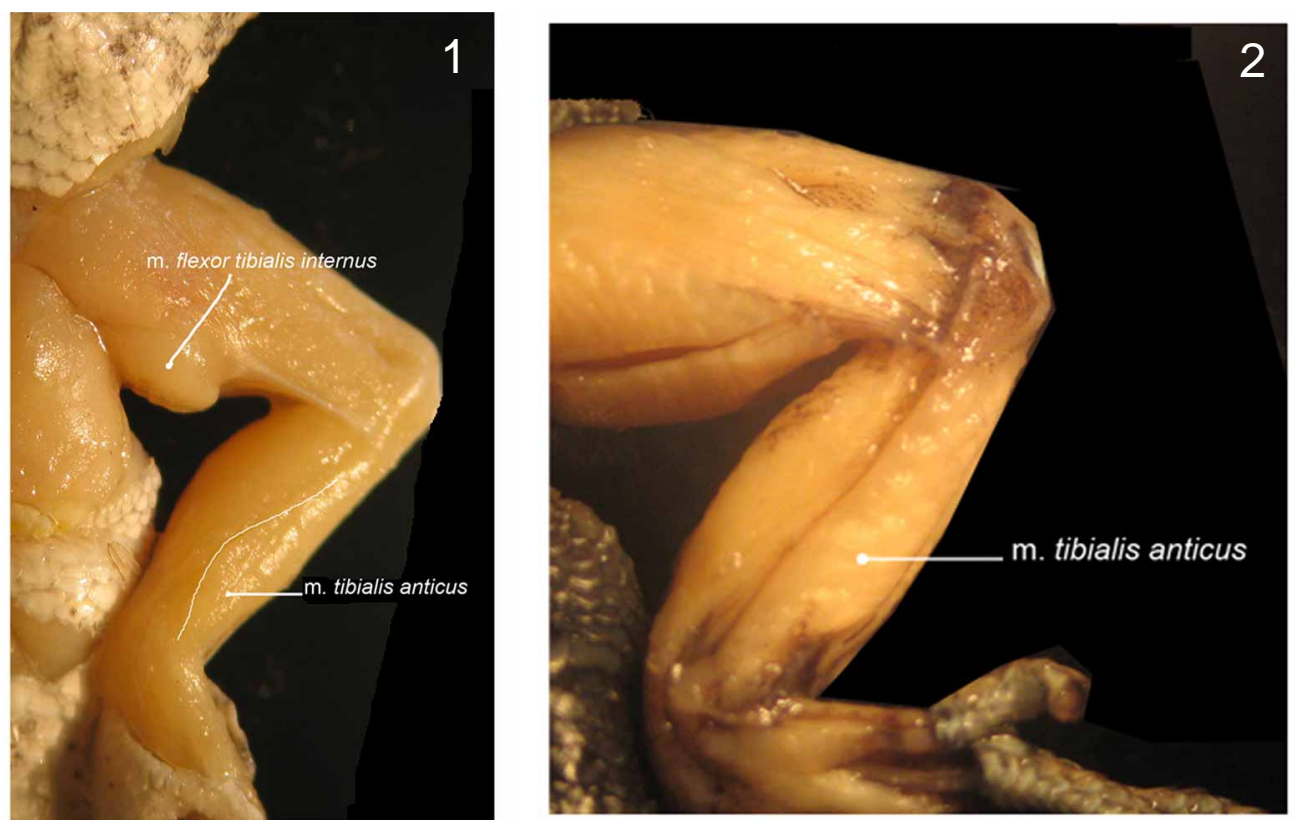

FIGURE 1-2. 1, Liolaemus darwinii; m. flexor tibialis internus with a bulge-like hypertrophy; m. tibialis anticus with a blade-like hypertrophy. 2, Liolaemus neuquensis; normal m. tibialis anticus
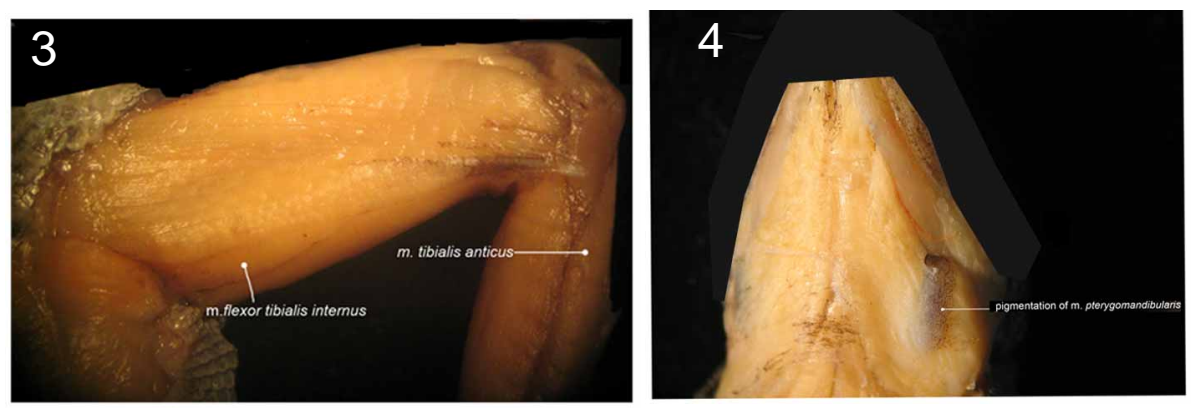

FIGURE 3-4. 3, Liolaemus talampaya; normal m. flexor tibialis internus. 4, Liolaemus sagei; Pigmented m. pterygomandibularis.

The underlying muscle may not bulge out the femoral patch although no species has a bulge without a femoral patch. In other words, members of the boulengeri group have a femoral patch, which usually but not always, is bulged out by the underlying muscle. It could also be inferred that both $L$. anomalus and $L$. pseudoanomalus, have femoral patches but no bulges (Table 1), the femoral scales being somewhat larger proximally, they grade gradually into smaller scales distally, so that there is no well marked "patch". This condition is not unlike that found in L. hatcheri.

M. tibialis anticus: it originates fleshly from the anterolateral internal face of the tibia, which is almost completely covered by the origin area of this muscle. It is a rather bulky muscle that inserts by a well-developed tendon on the proximal region of the metatarsal I. 
TABLE 2. Areas $\left(\mathrm{mm}^{2}\right)$ of $\mathrm{m}$. puboischiotibialis and $\mathrm{m}$. flexor tibialis internus and index of ratio between them.

\begin{tabular}{|c|c|c|c|c|}
\hline Figure 5 & Species & $\begin{array}{l}\text { Area m. flexor } \\
\text { tibialis interno }\end{array}$ & $\begin{array}{l}\text { Area m. pub- } \\
\text { oischiotibialis }\end{array}$ & Index \\
\hline 1 & Iguana iguana & 17,6 & 187,78 & 11,0070339976553 \\
\hline 2 & Liolaemus cei & 18,05 & 111,18 & 6,1595567867036 \\
\hline 3 & Liolaemus zullyi & 12,34 & 96,03 & 7,78200972447326 \\
\hline 4 & Liolaemus talampaya & 6,7 & 74,8 & 11,1641791044776 \\
\hline 5 & Liolaemus talampaya & 7,74 & 65,06 & 8,40568475452196 \\
\hline 6 & Liolaemus huacahuasicus & 8,53 & 45,99 & 5,3915592028136 \\
\hline 7 & Liolaemus escarchadosi & 7,26 & 45,65 & 6,28787878787879 \\
\hline 8 & Liolaemus petrophilus & 6,17 & 27,01 & 4,37763371150729 \\
\hline 9 & Liolaemus nеuquensis & 4,07 & 26,52 & 5,18095238095238 \\
\hline 10 & Liolaemus lineomaculatus & 3,16 & 25,37 & 8,02848101265823 \\
\hline 11 & Liolaemus robertmentensis & 2,68 & 25,86 & 9,64925373134328 \\
\hline 12 & Liolaemus escarchadosi & 4,2 & 21,76 & 6,51597051597052 \\
\hline 13 & Liolaemus bitaeniatus & 3,94 & 19,11 & 4,8502538071066 \\
\hline 14 & Liolaemus magellanicus & 3,08 & 18,78 & 6,0974025974026 \\
\hline 15 & Liolaemus chaltin & 2,66 & 14,68 & 5,5187969924812 \\
\hline 16 & Liolaemus puna & 2,14 & 15,16 & 7,08411214953271 \\
\hline 17 & Liolaemus elongatus & 10,05 & 75,76 & 7,53830845771144 \\
\hline 18 & Liolaemus salinícola 우 & 11,06 & 41,27 & 3,73146473779385 \\
\hline 19 & Liolaemus anomalus & 7,93 & 31,14 & 3,95964691046658 \\
\hline 20 & Liolaemus hatcheri & 6,16 & 30,22 & 4,90584415584416 \\
\hline 21 & Liolaemus albiceps 우 & 6,31 & 30,68 & 4,8621236133122 \\
\hline 22 & Liolaemus scapularis & 7,22 & 26,12 & 3,61772853185596 \\
\hline 23 & Liolaemus bibroni & 6,1 & 24,73 & 4,05409836065574 \\
\hline 24 & Liolaemus pseudoanomalus & 5,26 & 24,82 & 4,71863117870722 \\
\hline 25 & Liolaemus chacoensis & 3,71 & 18,84 & 5,07816711590297 \\
\hline 26 & Liolaemus pagaburoi & 3,23 & 11,77 & 3,64396284829721 \\
\hline 27 & Liolaemus multicolor & 12,92 & 35,34 & 2,73529411764706 \\
\hline 28 & Liolaemus boulengeri $\sigma^{x}$ & 11,99 & 22,95 & 1,91409507923269 \\
\hline 29 & Liolaemus abaucan $0^{x}$ & 11,3 & 22,31 & 1,97433628318584 \\
\hline 30 & Liolaemus inacayali & 9,97 & 19,01 & 1,90672016048144 \\
\hline 31 & Liolaemus darwinii & 12,92 & 12,15 & 0,940402476780186 \\
\hline 32 & Liolaemus salinícola $0^{x}$ & 22,81 & 23,1 & 1,01271372205173 \\
\hline 33 & Liolaemus albiceps $\sigma^{x}$ & 26,6 & 53,93 & 1,01271372205173 \\
\hline 34 & Liolaemus canqueli & 28,45 & 47,98 & 1,68646748681898 \\
\hline 35 & Liolaemus fitzingeri & 29,47 & 48,85 & 1,65761791652528 \\
\hline 36 & Liolaemus sagei & 34,18 & 55,44 & 1,62200117027501 \\
\hline 37 & Liolaemus cuyanus & 43,4 & 72,36 & 1,66728110599078 \\
\hline
\end{tabular}




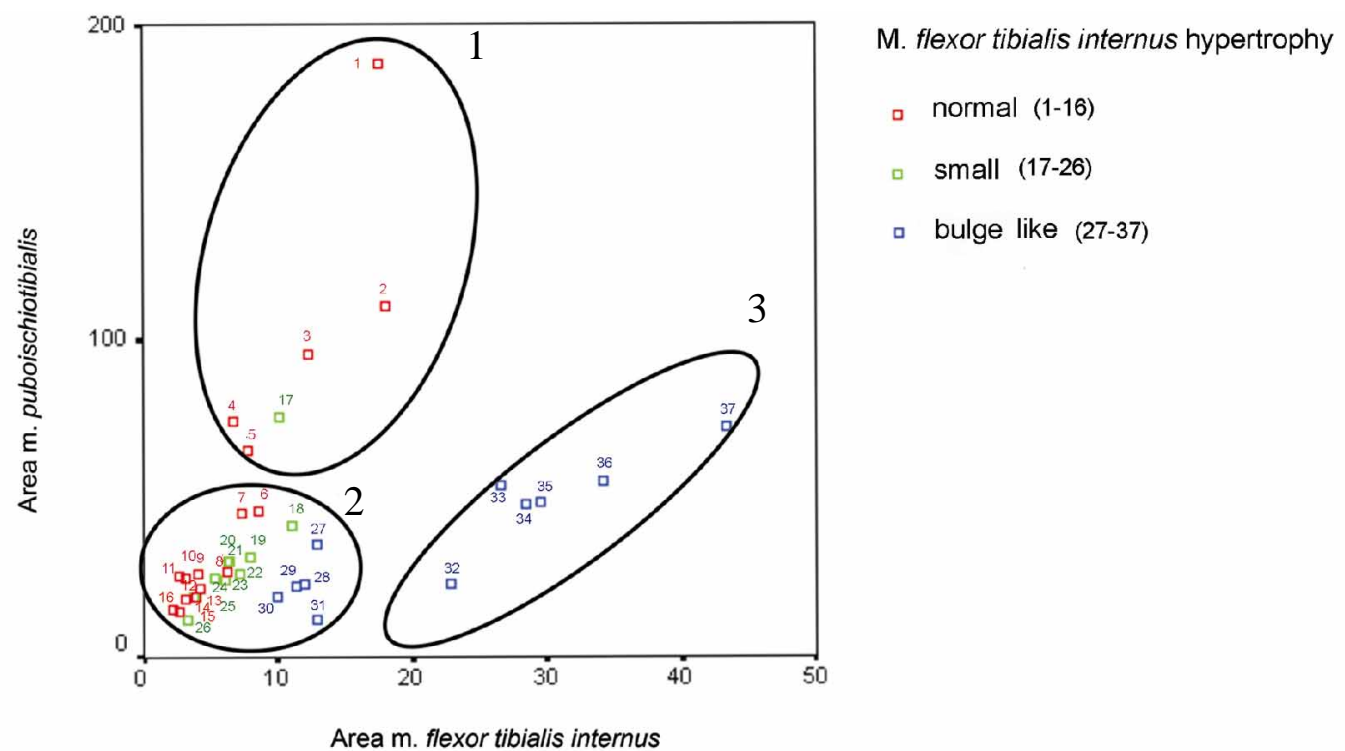

FIGURE 5. Ratio between areas of $\mathrm{m}$. puboischiotibialis and $\mathrm{m}$. flexor tibialis internus. $\mathrm{m}$. flexor tibialis internus hypertrophy: 1. Absent; 2. Small; 3. Bulge-like

Remarks. In many species of Liolaemus (Table 1), the insertion of the m. tibialis anticus is hypertrophied in relation to a blade-like hypertrophy of the tibia (Fig. 2).

Our results are totally congruent with Etheridge (1995). The species of the signifer group, (L. cf. anomalus, L. pseudoanomalus); the nitidus group (i.e. the chiliensis (Lesson), and lineomaculatus groups), and L. kingii, have a normal muscle. L. chacoensis has a normal muscle also. This character state includes L. chacoensis within the chiliensis group, supporting Etheridge's (1995) view, in contrast to those of Laurent (1983), Schulte (2000), Lobo and Abdala (2002), Morando (2004), and Abdala (2005) who include L. chacoensis within the boulengeri group. The species of the montanus group, including its subset, the boulengeri group, have a hypetrophied muscle. The character is exclusive of the Liolaemus montanus group (sensu Etheridge 1995).

M. pterygomandibularis: it originates on the external ventral surface of the anterior end of the epipterygoid by means of a clearly visible, strong and wide tendon. It runs ventral to the pterygoid, and is pear-shaped and very bulky at its posterior end. The muscle inserts on the ventromedial surface of the retroarticular process of the jaw.

Remarks. In many Liolaemus species, the perimysium of this muscle is very pigmented (Fig. 4). Some species have the perimysium lightly pigmented, and others have only very few pigmented points (Table 1). Most species of the boulengeri group present the epimysium very pigmented, except in $L$. darwinii (with both state characters, polymorphism), L cuyanus and L. xanthoviridis Cei \& Scolaro. Etheridge (2000) reported the perimysium without pigmentation in L. cuyanus. Most species of the montanus group have a strongly pigmented perimysium, being absent only in $L$. cf. andinus. Liolaemus 
kingii and the lineomaculatus group have the m. pterygomandibularis perimysium ligthly pigmented, and this is the case also for the chiliensis group. However it is very pigmented in L. talampaya Avila et al. and without pigmentation in L. robermertensis (both of the $L$. chiliensis group). Our results are not entirely congruent with those of Etheridge (1995), i.e., the perymysium is strongly pigmented in most, but not all members of the signifer group. In addition, it is also strongly pigmented in at least one species of the nitidus group.

\section{General remarks}

The analyzed samples show that variation in the muscular character is much more gradual than previously recognized. The only exception is the insertion of the m. tibialis anticus hypertrophied in relation to a bladelike hypertrophy of the tibia, which characterizes the montanus group of Etheridge (1995). Although the coding we used seems more complex, we think that it shows more precisely how subtle myology varies among the many different species of the genus. This continuity in myologycal characters makes them quite ambiguous, requiring the use of more aggressive search strategies for their cladistic analysis.

\section{Acknowledgments}

We are grateful to Richard Etheridge for his invaluable help and suggestions. Monique Halloy help us considerably.

\section{References}

Abdala, C. (2005) Sistemática y filogenia del grupo de L. boulengeri (Iguania: Liolaemidae: Liolaemus) en base a caracteres morfológicos y moleculares. Tesis Doctoral, Universidad Nacional de Tucumán, Tucumán, Argentina, 277 pp.

Etheridge, R. (1995) Redescription of Ctenoblepharys adspersa Tschudi, 1845, and the taxonomy of Liolaeminae (Reptilia: Squamata: Tropiduridae). American Museum Novitates, 3142, 1-34.

Etheridge, R.E. (2000) A review of the Liolaemus wiegmannii group (Squamata, Iguania, Tropiduridae), and a history of morphological change in the sand-dwelling species, Herpetological Monographs, 14, 293-352.

Etheridge, R. \& Espinoza, R. (2005) A semi-annotated bibliography and taxonomy of the Liolaeminae (Squamata: Iguania: Tropiduridae). Available from: http://www.sci.sdsu.edu/etheridge/ (accessed 15 October 2005).

Halloy, M., Etheridge, R. \& Burghardt, G.M. (1998) To bury in the sand: phylogenetic relationships among lizard species of the boulengeri group, Liolaemus (Reptilia: Squamata: Tropiduridae), based on behavioral characters. Herpetological Monographs, 12, 1-37.

Hoyos, J.M. (1990) Estudio cladístico en la familia Iguanidae (Sauria: Reptilia) con base en la musculatura posterior del miembro posterior. Revista Académica Colombiana de Ciencias, 17(66), 543-558.

Laurent, R.F. (1983) Contribución al conocimiento de la estructura taxonómica del género Liolae- 
mus wiegmanni (Iguanidae). Boletín de la Asociación Herpetológica Argentina, 1(3), 15-18.

Lobo, F. \& Abdala, C. (2002) La información cladística de un set de datos morfológicos en lagartos del género Liolaemus (Iguania: Liolaemidae). Cuadernos de Herpetología, 16, 137-150.

Moro, S.A. \& Abdala, V. (1998) Cranial myology of some species of Liolaemus and Phymaturus (Squamata: Tropiduridae: Liolaeminae). Amphibia-Reptilia, 19, 171-192.

Morando, M. (2004) Sistemática y Filogenia de grupos de Especies de los Géneros Phymaturus y Liolaemus (Squamata:Tropiduridae: Liolaemidae).Tesis Doctoral, Universidad Nacional de Tucumán, Tucumán, Argentina.

Russell, A.P. (1988) Limb muscles in relation to lizard systematics: a reappraisal. In: R. Estes \& G. Pregill (Ed.), Phylogenetic relationships of lizard families: Essays commemorating Charles L. Camp. Stanford University Press, pp. 119-281.

Russell, A.P. (1993) The Aponeurosis of the Lacertilian Ankle. Journal of Morphology, 218, 65-84.

Schulte, J.A. II, Macey, J.R. Espinoza, R.E. \& Larson, A. (2000) Phylogenetic relationships in the iguanid lizard genus Liolaemus: multiple origins of viviparous reproduction and evidence for recurring Andean vicariance and dispersal. Biological Journal of the Linnean Society, 69, $75-102$.

UTHSCSA (2002) ImageTool 3.0 program (developed at the University of Texas Health Science Center at San Antonio, Texas and available from the Internet by anonymous FTP from ftp:// maxrad6.uthscsa.edu). 
FML Fundación Miguel Lillo

MCN $\quad$ Museo de Ciencias Naturales

PT Proyecto Tupinambis

ACUNSA Anatomía Comparada Universidad Nacional de Salta

Diplolaemus darwinii: FML 16351. $48 \mathrm{~km}$ al Sur de Cerro Alto, por ruta provincial 23, camino a Comayo, departamento de Pilcaniyeu, Río Negro.

Iguana iguana without data.

Liolaemus abaucan: FML 25851-25856. Río Abaucan (S 27 55'; O 67 37’), departamento Tinogasta, Catamarca.

Liolaemus albiceps: MCN 668-675. Camino al Acay desde Estación Muñano, 8-9 km. 4100- 4200 m. Salta.

Liolaemus bibroni: FML 16345-346, 19 km al Oeste de Ingeniero Jacobacci, sobre ruta provincial 23, departamento 25 de Mayo, Río Negro.

Liolaemus bitaeniatus: FML 16772-779. Sierra de Medina, departamento de Burruyacú, Tucumán

Liolaemus boulengeri: FML 16334. $1 \mathrm{~km}$ de bifurcación de ruta nacional 40 y ruta provincial 17 , sobre ruta provincial 17, camino a Corcovado, departamento de Languiñeo, Chubut.

Liolaemus canqueli: FML 16335. 11 km al Este de Pocitos de Quichaura, departamento Languiñeo, Chubut.

Liolaemus ceii: FML 16348-350. 1 km al Este de las puertas del Parque Nacional Laguna Blanca, departamento Zapala, Neuquén.

Liolaemus cf andinus: FML 16838-843. Río el Balcón. Catamarca.

Liolaemus cf. boulengeri: FML 16369-374. Tres Cerros, departamento de Puerto Deseado, Santa Cruz.

Liolaemus cf. elongatus: FML 16347, $27.7 \mathrm{~km}$ al Sur de Ingeniero Jacobacci, sobre ruta provincial 6, departamento 25 de Mayo, Río Negro.

Liolaemus cf ornatus: FML 16846. Laguna de Antofagasta, Antofagasta de la Sierra, departamento Antofagasta de la Sierra, Catamarca.

Liolaemus cf. pseudoanomalus: FML 16336-337. La laja, departamento Albardón, San Juan.

Liolaemus chacoensis: FML 28881-21883 Caspi Corral departamento Figueroa, Santiago del E stero.

Liolaemus chaltin: MCN 233-234. 2 km al Norte de Abra Pampa (S 2241'819'; O 6543'532”; $3510 \mathrm{~m})$, departamento de Cochinoca, Jujuy.

Liolaemus darwinii: FML 13252-358. Valle Fértil, departamento de Valle Fértil, San Juan.

Liolaemus escarchadosi: MCN 1521-1533. Cordón de Los Escarchados, camino entrando por E stancia “La Martina”, frente a Laguna “Los Escarchados" (S 50²2.471'; O 71³5.578'; 830 m), Santa Cruz.

Liolaemus fitzingerii: FML 16359-364. Gruta de Lourdes, Puerto Deseado, departamento Puerto Deseado, Santa Cruz.

Liolaemus hatcheri: MCN 838-845. Cerro Beltza (S 47 59.617’; O 7141.187’); Río Chico departamento de Río Chico, Santa Cruz.

Liolaemus huacahuasicus: FML 16826-836. Huaca Huasis (S 26³9’28.3”; O 6544’36.4”), departamento Tafí Viejo, Tucumán.

Liolaemus inacayali: FML 16339-40. A $2.3 \mathrm{~km}$ al Sur de la intersección de ruta provincial 76 y 23 , por ruta provincial 76, a $3.4 \mathrm{~km}$ al Sur de Ingeniero Jacobacci, departamento 25 de Mayo. (S $41^{\circ} 20^{\prime} 022$ "; O 69²8'23.3", 898 m), Río Negro.

Liolaemus irregularis: PT 3367. $5 \mathrm{~km}$ al Oeste de San Antonio de los Cobres, departamento Los Andes, Salta. 
Liolaemus kingii: FML 16343-344. $11 \mathrm{~km}$ al Este de Pocitos de Quichaura, departamento Languiñeo. FML 16342. $4 \mathrm{~km}$ al Oeste de la intersección entre ruta nacional $40 \mathrm{y}$ ruta provincial 12, Esquel, departamento Futaleufú, Chubut.

Liolaemus koslowskyi: FML 16805-809. Salar de Pipanaco, departamento de Pomán, Catamarca.

Liolaemus lineomaculatus: MCN 879-881. Perito Moreno, ruta del Oeste (S 46³0.402'; O $\left.71^{\circ} 00.423^{\prime}\right)$; Lago Buenos Aires, departamento de Lago Buenos Aires, Santa Cruz.

Liolaemus loboi: FML 16365-368. Kilómetro 1022, 149 km al Sur de Zapala, sobre ruta nacional 40, departamento Zapala, Neuquén.

Liolaemus magellanicus: MCN 852-861. Cordón de Los Escarchados, Camino entrando por La Martina (S 50²2.702'; O 71³6.868'; 960 m); Santa Cruz.

Liolaemus multicolor: FML 16341. Abra Pampa, departamento Cochinoca, Jujuy.

Liolaemus neuquensis: ACUNSA 753-754. Laguna Las Mellizas, frente a Pozo Geotérmico, 2.5 $\mathrm{km}$. Al Sureste de Termas de Copahue, departamento Ñorquin, Neuquén.

Liolaemus pagaburoi: FML 16793-804. Ciénaga Grande, San José de Chasquivil (S 26 41'35.5”; O 65³9'37.5”), departamento Tafí Viejo, Tucumán.

Liolaemus petrophilus: MCN 1346. Cerro frente al Sombrero, departamento Paso de Indios, Chubut.

Liolaemus pseudoanomalus: PT 3876. departamento Castro Barros, $2.5 \mathrm{~km}$ al Este de Anillaco, La Rioja.

Liolaemus pulcherrimus: FML 16780-781. Palca de Aparzo, departamento Humahuaca, Jujuy

Liolaemus puna: MCN 225-227. Camino de Humahuaca a Chorcán (S 2310’761”; O 6511’709”; $4251 \mathrm{~m})$, Jujuy.

Liolaemus robertmertensis: FML 16790-792. Estancia Río Blanco, 30 km al Sur de Andalgalá, departamento Pomán, Catamarca

Liolaemus sagei: FML 16375-379. 1 km al Este de las puertas del Parque Nacional Laguna Blanca, departamento Zapala, Neuquén.

Liolaemus salinícola: FML 16872-789. Medanitos por ruta 34 entre Fiambalá y Palo Blanco, departamento de Tinogasta, Catamarca.

Liolaemus scapularis: PT 4131. San Antonio $40 \mathrm{~km}$ Sur de Santa Maria sobre ruta Nacional 40, departamento Santa Maria, Catamarca.

Liolaemus talampaya: ACUNSA 216-233. Talampaya, La Rioja.

Liolaemus uspallatensis: FML 16474-475. Barreal Blanco, departamento Iglesias, San Juan.

Liolaemus xanthoviridis: FML 16338. $100 \mathrm{~km}$ al Norte de Camarones, departamento Florentino Ameghino, Chubut.

Liolaemus yanalcu: MCN 926. Camino al Acay desde estación Muñano. (5-6 km) departamento de Los Andes, Salta.

Liolaemus zullyi: MCN 1539-1541. $37 \mathrm{~km}$ al Sur de Los Antiguos, camino a Monte Cevallos (S 46 46.237'; O 71 ${ }^{\circ} 45.200^{\prime}$ ); departamento de Lago Buenos Aires, Santa Cruz.

Phymaturus antofagastensis: FML 16767-771. La Gruta, por ruta provincial 45, $20 \mathrm{~km}$ antes de Paso San Francisco, departamento de Tinogasta, Catamarca. 